\title{
Responses to the Comments on global climate change and non-violent civil disobedience
}

\author{
John Lemons ${ }^{1, *}$, Donald A. Brown ${ }^{2}$ \\ ${ }^{1}$ Department of Environmental Studies, University of New England, Biddeford, Maine 04005, USA \\ ${ }^{2}$ Rock Ethics Institute, Penn State University, Pennsylvania 16802, USA
}

We thank those who commented on our article for helping foster our goal of initiating greater discussion about global climate change (GCC) and non-violent civil disobedience (NVCD). We see Gupta's comment (Gupta 2011, this issue) as reinforcing our points, but with the benefit of providing more understanding of Gandhi's influence in policies and actions that should be useful in future discourse about GCC and NVCD. Likewise, Ott seems to be in basic agreement with our views (Ott 2011, this issue). However, he reminds us that the general media needs to increasingly raise questions about mitigation and do a better job of framing GCC in an ethical context, along with the need to obtain solidarity with people in other nations, such as those of the European Union. Ott (2011) also raises questions we had not dealt with, namely: Should laws in the USA be rigidly applied to discourage NVCD as much as possible? Or, should laws better tolerate NVCD by removing protestors from protest sites, but by accusing them in court much less frequently? An affirmative answer to the latter question might seem to constitute reasonable law and policy. However, given the urgent need to act, based on the best scientific information available, attempts to change NVCD laws might take considerable time or might not be successful at all and, hence, contravene prospects for mitigating GCC that could occur as a result of a successful NVCD movement. However, we do agree that the question deserves study. Rosales (2011, this issue) makes an important contribution to the discourse on NVCD because he emphasizes why and how (by determining educational goals and teaching approaches) a greater focus on NVCD can be made at the undergraduate level. Rosales (2011) also reminds us that one of the purposes of NVCD is to establish records of action to right wrongs in order to help educate people about, for example, social or environmental injustice.
We are well aware of Dernbach's points (Dernbach 2011, this issue): (1) that laws are stacked against those who protest using NVCD; (2) that there is a need to connect people interested in considering the use of NVCD from a wider range of disciplines and areas than we described; and (3) that, despite the success of the 'necessity' defense used in the Kingsnorth case, there are huge legal standards to be upheld in order to meet the burdens of proof in other similar situations. The most troublesome issue rightly pointed out by Dernbach (2011) is that GCC mitigation has not become a broad social movement and, consequently, might doom NVCD actions to failing or being counterproductive. While we agree with Dernbach (2011) about the troublesome nature of GCC mitigation not being part of a broad social movement, we have suggested that NVCD could be a catalyst to spur meaningful action to mitigate GCC. At this point in time, no one can predict whether NVCD would be successful or not. Finally, the philosophers we mentioned in our paper that have informed thinking about NVCD generally have argued that it is justified when individuals are attempting to change an unjust governmental law or policy (and recourse to lawful means have been exhausted) and, presumably, this transcends strategic political considerations on the level of public support for NVCD because decisions to be engaged in NVCD extend beyond mere utilitarian or pragmatic political considerations.

Bosworth's Comment (Bosworth 2011, this issue) raises a number of complex issues. Because of space limitations, we respond to the 3 most fundamental problems with his argument. Bosworth (2011) is correct in stating that our paper focused on mitigation of greenhouse gases (GHGs) to address the ethical and other dimensions of GCC. We recognize that adaptation needs to be part of any effectual response to the problem of GCC. However, Bosworth's discussion about the need 
for adaptation, which at first glance sounds reasonable, ignores the extensive body of scientific literature published after the IPCC Fourth Assessment Report and referenced in our paper. The conclusions to be drawn from the literature are as follows: (1) GHG emissions have exceeded IPCC's worst case scenario; (2) climate sensitivity is higher than previously thought; (3) nonlinear positive feedbacks and dynamical melting of the West Antarctic and Greenland ice sheets are occurring; and (4) warming oceans and melting of permafrost pose risks of release of methane hydrates. The upshot of these conclusions is that there is a high probability that serious and irreversible changes will happen on decadal time-scales unless GHG emissions peak and begin to decline before 2020, regardless of adaptation actions (see Lemons \& Brown 2011,p. 4-5, section 'The science of global climate change'). Further, adaptation to many GCC impacts is probably not possible. What conceivable adaptation could be made to the millions of people from, say, the Nile River Delta or Bangladesh that would be affected by only a few meters rise in sea level? What about the ca. 7 million people from small island nations that are already losing, or will lose, their nations and have the status of 'environmental refugees'? Yes, these displaced people will be able to relocate in one or more countries, but such a situation seems to be more a desperate and wrongful tragedy than is suggested by the term 'adaptation'. Further, if rising ocean temperatures begin melting methane hydrates, for all practical purposes this will create irresolvable impacts for which no conceivable adaptation is possible, at least for the majority of people in the world.

Another problem with Bosworth's Comment is his emphasis on possible adverse economic consequences of GHG mitigation. We agree that assessing and trying to reduce adverse economic consequences are important. Yet, his examples of the kinds of adverse economic hardships stemming from mitigation of GHGs exclusively focus on American and European Union investments of pension fund managers and others who have invested in transitioning to a low-carbon economy; there is no mention of the economic advantages of mitigation to the $80 \%$ or so of humankind which lives in developing nations and historically has done little to contribute to GCC.

Finally, Bosworth (2011, p. 14) states: 'The complexity of the economics and potential for unforeseen hardships based on investment and perception of lowcarbon economies force the issue of NVCD away from moral duties or ecological justice towards much more convoluted ideals, potentially placing private investment, governments and other stakeholders in ecological equilibrium disturbed by GCC at odds'. Within the realm of contentious politics, his statement might be accurate, but it discounts NVCD's justification in sup- port of individuals who believe that morally wrong laws and public policies need to be changed, and who have strong reason and evidence to believe that recourse to lawful means to change them will not work. Given the extent to which economic motives are responsible for GCC, surely economists and investors and public policy decision-makers can figure out a way to avoid undue economic hardships and at the same time address the need for intra- and intergenerational equity in the mitigation of GHGs.

Dorjderem (2011, this issue) tackles our paper from within the context of theories of political philosophy. He writes (including a quote from Rawls 2005, p. 176) that: "civil disobedience opposes the '... legally established democratic authority'...; and those policies and laws that were agreed or accepted upon the direct or indirect consent by the ruling majority. If they were well accepted, we can consider those policies and laws to be desirable and fair, other things being equal" (Dorjderem 2011, p. 34). In the context of GCC, 'other things being equal' does not exist. As we have seen, people who have contributed little to the problem share a disproportionate proportion of the harm and burdens (as do future generations), and international law does not, for the most part, allow them to seek recourse from the very nations who are disproportionately causing GCC problems.

Dorjderem (2011) also brings up conflicts between Satyagraha, with its emphasis on the pursuit of truth, and liberalism with its accentuated respect for pluralistic tolerance, autonomy, self-determination, and sovereignty, regardless of whether truth (or substantive content) becomes a casualty. Dorjderem clearly sides with tolerating '...the views of others as other autonomous people that are equally entitled to pursue their own visions' (Dorjderem 2011, p. 36). Quoting Nagel (1987, p. 231), Dorjderem writes: ' . . it is alright for the majority to use political power in the service of their opinion.' It seems nonsensical to us that the conflict between truth and tolerance, within the liberalism that Dorjderem describes, should be taken seriously, given the factual extent to which people in developing nations are harmed disproportionately by developed countries through emissions of GHGs. If taken to the extreme, his argument allows the will of the majority to be imposed upon the minority in any circumstance. Further, in terms of the high value that Dorjderem apparently places on nations' sovereignty, we remind him that the United Nations Framework Convention on Climate Change (UNFCCC 1992, p. 1) places '...responsibility to ensure that activities within their jurisdiction or control do not cause damage to the environment of other States or of areas beyond the limits of national jurisdiction'. The United Nations Human Rights Council (UNHRC) has also adopted resolutions about GCC. The USA has rati- 
fied the UNFCCC and is a member of the UNHRC and therefore has a mandate to fulfill obligations to which it has agreed. Finally, Dorjderem ignores philosophical cosmopolitanism as a contravening example to his arguments. In fact, this serves as a reminder that we should have mentioned ways in which this philosophy might justify NVCD actions to address GCC.

\section{LITERATURE CITED}

Bosworth AS (2011) Potential for conflicting interests in those who participate in NVCD. Ethics Sci Environ Polit 11:13-15

Dernbach JC (2011) Can the battle against climate change become an effective social movement? Ethics Sci Environ Polit 11:27-30

Editorial responsibility: Darryl Macer,

Bangkok, Thailand
Dorjderem A (2011) Global climate change: interests of foreigners in civil disobedience. Ethics Sci Environ Polit 11:31-37

> Gupta A (2011) Responding to global climate change: the Gandhian way. Ethics Sci Environ Polit 11:19-21

Lemons J, Brown DA (2011) Global climate change and non-violent civil disobedience. Ethics Sci Environ Polit 11:3-12

Nagel T (1987) Moral conflict and political legitimacy. Philos Public Affairs 16:215-240

Ott K (2011) Is civil disobedience appropriate in the case of climate policies? Ethics Sci Environ Polit 11:23-26

Rosales J (2011) Higher education and non-violent civil disobedience. Ethics Sci Environ Polit 11:17-18

United Nations Framework Convention on Climate Change (UNFCCC) (1992) Bonn. Availabe at http://unfccc.int/ resource/docs/convkp/conveng.pdf

Submitted: February 9, 2011; Accepted: February 15, 2011 Proofs received from author(s): May 12, 2011 